LWSA

PAPER - OPEN ACCESS

Tantangan Dan Harapan Gugus Tugas Diversi dan Keadilan Restoratif Dalam Perlindungan Anak Yang Berkonflik Dengan Hukum di Kota Medan

\author{
Author \\ : Arif Arif \\ DOI \\ : 10.32734/lwsa.v1i1.156 \\ Electronic ISSN \\ : 2654-7058 \\ Print ISSN \\ : 2654-7066
}

Volume 1 Issue 1 - 2018 TALENTA Conference Series: Local Wisdom, Social and Arts

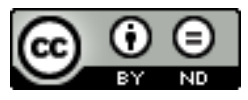

This work is licensed under a Creative Commons Attribution-NoDerivatives 4.0 International License.

Published under licence by TALENTA Publisher, Universitas Sumatera Utara
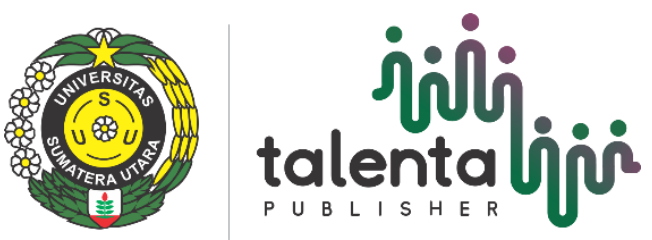


\title{
Tantangan \& Harapan Gugus Tugas Diversi dan Keadilan Restoratif Dalam Perlindungan Anak Yang Berkonflik Dengan Hukum di Kota Medan
}

\author{
Arif $^{\text {a }}$ Pendastaren Tarigan ${ }^{\text {a }}$ Rosmalinda ${ }^{\text {a }}$ Asmaul Husna ${ }^{\text {a* }}$ \\ ${ }^{a}$ Fakultas Hukum, Universitas Sumatera Utara, Medan-20155
}

arifbsn@yahoo.com, pendastaren_tarigan@yahoo.co.id,*rz_linda@yahoo.com, anafahusna@gmail.com

\begin{abstract}
Abstrak
Penelitian yang berjudul - Model Pendampingan Hukum Bagi Anak yang Berhadapan dengan Hukum di Kota Medan dan Kabupaten Deli Serdang didukung oleh DIKTI skim Penelitian Unggulan Perguruan Tinggi (PUPT). Pada tahun Pertama ini penelitian memiliki 3 tujuan, Pertama, menjelaskan situasi PendampinganHukum Bagi Anak yang berkonflik Hukum Di Kota Medan \& Deli Serdang sebelum penerapan UU No 11 Tahun 2012 Tentang SPPA. Kedua, menjelaskan situasi PendampinganHukum Bagi Anak Yang Berhadapan Dengan Hukum Di Kota Medan \& Deli Serdang setelah penerapan UU No 11 Tahun 2012 Tentang Sistem Peradilan Pidana Anak (SPPA). Menggunakan metode penelitian normatif empiris, penelitian ini melakukan pengumpulan peraturan hukum terkait, kasus terkait dan Wawancara Mendalam dengan 21 Informan (15 Perempuan dan 6 Laki-Laki) di Medan yang terdiri dari Aparat Penegak Hukum (APH) dan Organsasi Bantuan Hukum (OBH). Satu temuan penting penelitian ini adalah, pada tahun 2016, Pemerintah Kota Medan telah memiliki Gugus Diversi dan Keadilan restoratif berdasarkan SK Walikota No 463/384.K/III/2016. Keberadaan ini merupakan satu jawab dari hadirnya UU No 11 Tahun 2012 tentang SPPA yaitu pelaksanaan diversi dengan pendekatan Keadilan Restoratif. Berdasarkan hasil temuan sementara Peneliti, kehadiran Gugus Tugas ini tentunya memiliki tantangan yang berbanding lurus dengan harapan atas keberadaannya. Beberapa Tantangan Gugus Tugas ini, pertama tingkat pemahaman APH tentang Diversi dan Keadilan restoratif. Hasil penelitian memperlihatkan bahwa 90,48\% APH paham tentang diversi namun hanya 23,81\% APH yang mengetahui keadilan Restoratif. Kedua, tingkat pengalaman APBH; Hanya 28,57\% APH yang menyatakan pernah terlibat dalam penerapan diversi. Berdasarkan hasil penelitian sementara ini, Peneliti berharap pemerintah Pusat dan pemerintah Daerah terutama kota Medan dapat menyusun dan melaksanakan sosialisasi program terkait diversi dan Keadilan Restoratif sehingga Perlindungan bagi Anak yang Berkonflik dengan Hukum dapat terpenuhi sesuai dengan peraturan yang berlaku.
\end{abstract}

Kata Kunci: Tantangan; Harapan, Pendampingan AKH; Kota Medan; UU SPPA 


\section{Pendahuluan}

Anak sama dengan orang dewasa umumnya, mereka memiliki harkat dan martabat sebagai manusia seutuhnya. Secara khusus, untuk kebutuhan tumbuh kembangnya, mereka mendapat perlindungan dan perhatian secara khusus termasuk anak yang berhadapan dengan hukum.

Persinggungan dengan sistem peradilan pidana menjadi titik permulaan anak berhadapan dengan hukum. Istilah sistem peradilan pidana menggambarkan suatu proses hukum yang diterapkan pada seseorang yang melakukan tindak pidana atau melanggar kesesuaian hukum pidana. Dengan demikian istilah sistem peradilan pidana anak dipergunakan untuk menggambarkan sistem peradilan pidana yang dikonstruksikan pada anak. ${ }^{7}$

Terkait upaya memberikan perlindungan terhadap anak yang berhadapan dengan hukum, sistem peradilan pidana anak harus dimaknai secara luas, ia tidak hanya dimaknai hanya sekedar penanganan anak yang berhadapan dengan hukum semata. Namun sistem peradilan pidana anak harus juga dimaknai mencakup akar permasalahan (root causes) mengapa anak melakukan perbuatan pidana dan upaya pencegahannya. Lebih jauh, ruang lingkup sistem peradilan pidana anak mencakup banyak ragam dan kompleksitas isu mulai dari anak melakukan kontak pertama dengan polisi, proses peradilan, kondisi tahanan, dan reintegrasi sosial, termasuk pelaku-pelaku dalam proses tersebut. Dengan demikian, istilah sistem peradilan pidana anak merujuk pada legislasi, norma dan standar, prosedur, mekanisme dan ketentuan, institusi dan badan yang secara khusus diterapkan terhadap anak yang melakukan tindak pidana. ${ }^{8}$

Mengacu pada proses ini, maka terdapat 3 (tiga) tahap peradilan anak, tahap pertama, mencakup pencegahan anak dari tindak pidana. Tahap ini meliputi implementasi tujuan kebijakan sosial yang memungkinkan anak dalam pertumbuhannya sesuai dengan kepentingan terbaiknya. Tahap kedua, ditandai anak bersentuhan dengan prosedur formal sistem peradilan pidana. Tahap ini merupakan bentuk tanggung jawab anak melalui proses peradilan pidana. Tahap ketiga, resosialisasi diawali dari proses isolasi di lembaga pemasyarakatan sampai pada tahap pembebasan anak. ${ }^{9}$.

\section{Anak dan Sistem Peradilan Pidana Anak (SPPA)}

Terminologi internasional maupun berdasarkan Undang-Undang yang digunakan untuk menyebut anak yang melakukan pelanggaran hukum adalah "Anak yang Berhadapan dengan Hukum". Sejak disadari bahwa anak juga melakukan pelanggaran hukum, perdebatan tentang bagaimana cara yang terbaik untuk menghadapinya terus menerus berlangsung.

Salah satu upaya pemerintah dalam melakukan pencegahan dan penanggulangan kenakalan yaitu dengan menyelenggarakan sistem peradilan pidana anak (Juvenile Justice System) melalui UU No. 11 Tahun 2012 tentang Sistem Peradilan Pidana Anak yang menggantikan UU No. 3 Tahun 1997 tentang Pengadilan Anak yang dilakukan dengan tujuan agar dapat terwujud peradilan yang berar-benar menjamin perlindungan kepentingan terbaik terhadap anak yang berhadapan dengan hukum sebagai penerus bangsa. ${ }^{10}$

Pasal 1 ayat (1) UU No. 11 Tahun 2012 tentang Sistem Peradilan Pidana Anak menyatakan bahwa sistem peradilan pidana anak adalah keseluruhan proses penyelesaian perkara anak yang berhadapan dengan hukum, mulai dari tahap penyelidikan sampai dengan tahap pembimbingan setelah menjalani pidana. Sedangkan Pasal 1 ayat (7) UU No. Tahun 2012 tentang Sistem Peradilan Pidana Anak, menyatakan bahwa diversi adalah pengalihan penyelesaian perkara anak dari proses peradilan pidana ke proses luar peradilan pidana.

Sebelum berlakunya Undang-Undang No 11 Tahun 2012 tentang Sistem Peradilan Pidana Anak (SPPA) maka Undang Undang yang berlaku dan dipergunakan oleh aparat penegak hukum adalah Undang Undang No 3 Tahun 1997 tentang Pengadilan Anak. Ada beberapa hal yang membedakan keduanya seperti terlihat dalam tabel dibawah ini.

\begin{tabular}{lll}
\hline Perbedaan & UU No 3 Tahun 1997 & UU No 11 Tahun 2012 \\
\hline Definisi Anak & Anak, Anak Nakal, dan Anak & Anak yang Berhadapan dengan Hukum, Anak yang \\
& Didik Pemasyarakatan. & Berkonflik dengan Hukum, Anak yang Menjadi \\
& & Korban Tindak Pidana, dan Anak yang Menjadi \\
& Saksi Tindak Pidana
\end{tabular}




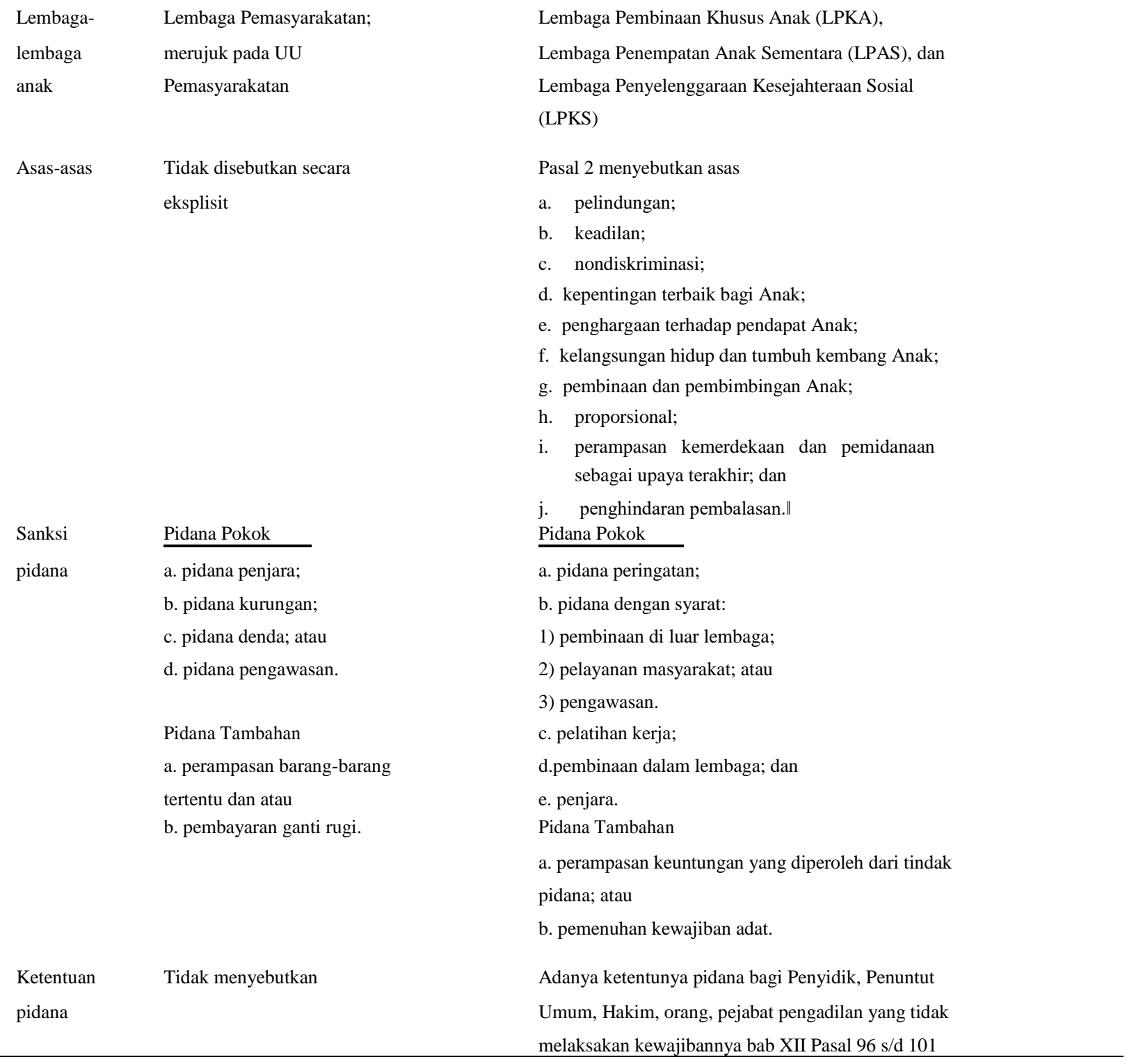

Merujuk pada tabel perbedaan diatas maka terlihat bahwa Asas ultimum remedium (the last resort principle) terhadap anak yang berkonflik dengan hukum dalam proses hukum belum menjadi hal yang uatma. Namun keharusannya berubah dengan berlakunya UU No 11 tahun 2012. Pada SPPA, asas ini harus diterapkan dengan disebutkannya Diversi.

Diversi adalah proses yang telah diakui secara internasional sebagai cara terbaik dan paling efektif dalam menangani anak yang berhadapan dengan hukum. Intervensi terhadap anak yang berhadapan dengan hukum sangat luas dan beragam, tetapi kebanyakan lebih menekankan pada penahanan danpenghukuman, tanpa peduli betapa ringannya pelanggaran tersebut atau betapa mudanya usia anak tersebut.

Diversi dimaksudkan untuk menghindari dan menjauhkan anak dari proses peradilan sehingga dapat menghindari stigmatisasi terhadap anak yang berhadapan dengan hukum dan diharapkan anak dapat kembali ke dalam lingkungan 
sosial secara wajar. Oleh karena itu, sangat diperlukan peran serta semua pihak dalam rangka mewujudkan hal tersebut. Proses itu harus bertujuan pada terciptanya keadilan restoratif, baik bagi anak maupun bagi korban.

Keadilan restoratif merupakan suatu proses diversi yaitu dimana semua pihak yang terlibat dalam suatu tindak pidana tertentu bersama-sama mengatasi masalah serta menciptakan suatu kewajiban untuk membuat segala sesuatunya menjadi lebih baik dengan melibatkan korban, anak, dan masyarakat dalam mencari solusi untuk memperbaiki, rekonsiliasi, dan menenteramkan hati yang tidak berdasarkan pembalasan. Penerapan ketentuan diversi merupakan hal yang penting, karena dengan diversi hak-hak asasi anak dapat lebih terjamin, dan menghindarkan anak yang berhadapan dengan hukum dari stigma sebagai anak nakal, karena tindak pidana yang diduga melibatkan seorang anak sebagai pelaku dapat ditangani tanpa perlu melalui proses hukum.

\section{Gugus Tugas Diversi \& Keadilan Retoratif Kota Medan}

Pada pelaksanaannya, diversi membutuhkan pendampingan hukum yang membantu menyelesaikan perkara anak. Sebutan pendamping dalam sistem hukum Indonesia dikenal sejak diundangkan-nya undang-undang No. 23 tahun 2002 tentang Perlindungan Anak (UUPA). Pendamping menurut pasal 1 ayat 12 UU Perlindungan Anak adalah pekerja sosial yang mempunyai kompetensi profesional dalam bidangnya, UU Perlindungan anak tidak menjelaskan secara khusus peran dari seorang pendamping dalam menangani korban.

Istilah pendamping dapat kita temukan juga dalam pasal 17 UU PKDRT disebutkan bahwa \|Relawan Pendamping adalah orang yang mempunyai keahlian melakukan konseling, terapi dan advokasi guna penguatan dan pemulihan diri korban kekerasanll. Dalam undang-undang tersebut pada pasal 23 menyebutkan peran pendamping adalah sebagai berikut :

1. Menginformasikan kepada korban akan haknya untuk mendapatkan seorang atau beberapa orang pendamping.

2. Mendampingi korban di tingkat penyidikan, penuntututan atau tingkat pemeriksaan pengadilan dengan membimbing korban untuk secara obyektif dan lengkap memaparkan kekerasan dalam rumah tangga yang dialaminya.

3. Mendengarkan secara empati segala penuntututan korban sehingga korban merasa aman didampingi oleh pendamping

4. Memberikan dengan aktif penguatan secara psikologis dan fisik kepada korban. ${ }^{11}$

Berdasarkan hasil Penelitian yang berjudul "Model Pendampingan Hukum Bagi Anak yang Berhadapan dengan Hukum di Kota Medan dan Kabupaten Deli Serdang didukung oleh DIKTI skim Penelitian Unggulan Perguruan Tinggi (PUPT).Temuan awal Penelitian hingga tulisan ini disusun menggunakan metode penelitian normatif deskriptif dimana Penelitian dilakukan dengan menelaah aturan hukum yang terkait dengan aturan Hukum tentang Anak yang berhadapan dengan Hukum seperti UU tentang SPPA,

tentang Organisasi Bantuan Hukum termasuk melihat aturan hukum tingkat kota seperti Kota Medan. Selanjutnya, Penelitian dilakukan dengan Wawancara Mendalam dengan 21 Informan (15 Perempuan dan 6 Laki-Laki) di Medan yang terdiri dari Aparat Penegak Hukum (APH) dan Organsasi Bantuan Hukum (OBH).

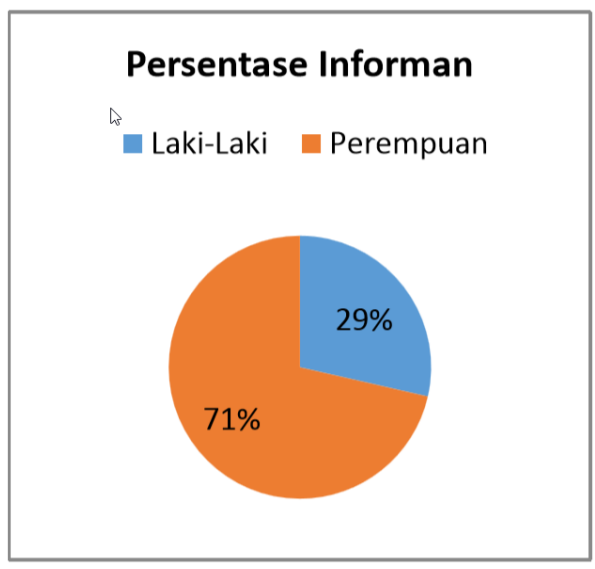


Khusus untuk Kota Medan, Peneliti memperoleh informasi bahwa sejak 10 Maret 2016. Kota Medan telah memiliki Gugus Tugas Kota Medan berdasarkan SK Walikota No 463/384.K/III/2016. Berdasarkan SK ini disebutkan bahwa Gugus Tugas ini diharapkan dapat menjadi lembaga kordinasi pelaksanaan diversi dengan penedekatan Keadilan Restoratif, Untuk itu Gugus Tugas memiliki beberapa bidang termasuk didalamnya bidang diversi dan keadilan restoratif.

Merujuk pada harapan yang disebutkan dalam SK Gugus Tugas, penelitian ini menemukan tantangan bagi Gugus Tugas Kota Medan terkait dengan Pengetahun dan pengalaman pengurus dan anggota tim Gugus Tugas Diversi dan Keadilan restoratif Kota Medan mengingat sepanjang tahun 2015, APH kota Medan telah berhasil melaksanakan diversi pada 24 kasus.
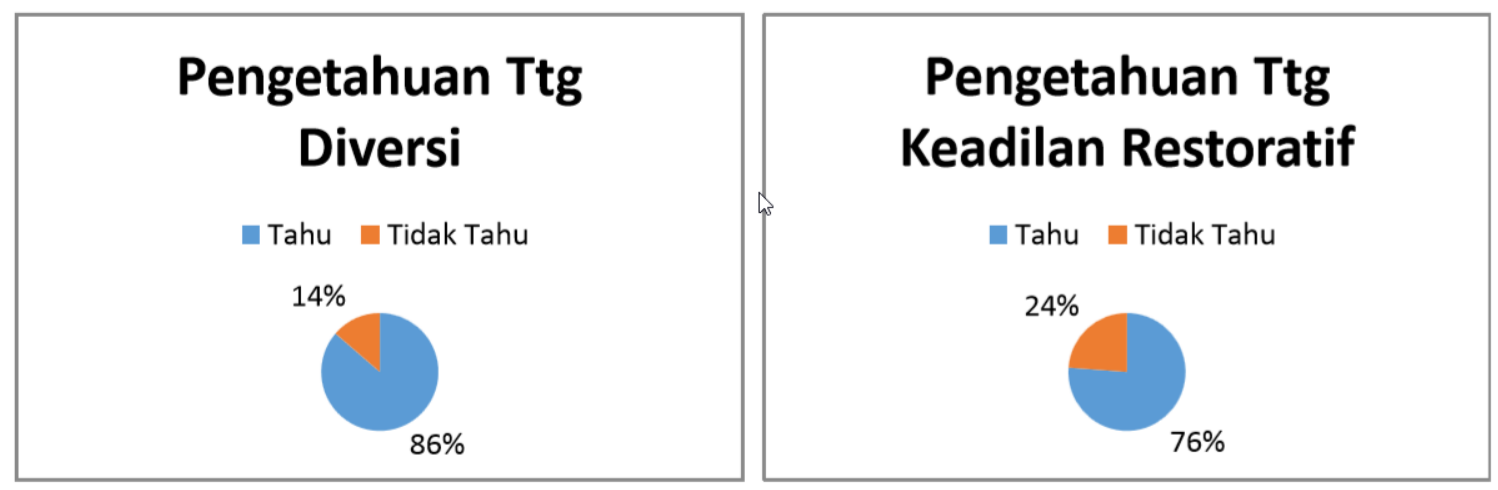

Tantangan yang menjadi perhatian Peneliti dalam pelaksanaan diversi di kota Medan adalah tingkat pemahaman APH tentang Diversi dan Keadilan restoratif. 19 dari 21 informan atau 90,48\%

mengetahui pengertian diversi, sedangkan 9,52\% tidak mengetahui diversi. Selanjutnya untuk keadilan restoratif hanya23,81\% yang mengetahuisedangkan $76,19 \%$ tidak mengetahui apa yang dimaksud dengan keadilan restoratif.

Tantangan lain penerapan diversi dan keadilan restoratif adalah pengalaman APH dalam melaksanakan Diversi. Hanya 6 informan $(28,57 \%)$ menyatakan pernah terlibat dalam penerapan diversi seperti Hakim, Jaksa dan BAPAS Kelas 1 Kota Medan sedangkan 15 informan (71,43\%) menyatakan belum pernah melaksanakan diversi.

\section{Kesimpulan dan Saran}

Sebagai kesimpulan pada temuan awal penelitian ini adalah Pelaksanaan diversi dikota Medan belumlah mencapai kata maksimal hal ini disebabkan oleh beberapa faktor diantaranya kurangnya pengetahuan aparat penegak hukum mengenai diversi dan paradigma masyarakat terhadap hukuman bagi anak yang berhadapan dengan hukum. Untuk itu disarankan adanya sosialisasi mengenai Pelaksanaan Diversi tidak hanya bagi Aparat Penegak Hukum tetapi juga ikut melibatkan Masyarakat, sehingga apabila terjadi perkara anak tidak selalu berakhir pada persidangan. Lebih lanjut, Peneliti berharap pemerintah Pusat dan pemerintah Daerah terutama kota Medan dapat menyusun dan melaksanakan sosialisasi program terkait diversi dan Keadilan Restoratif sehingga Perlindungan bagi Anak yang Berkonflik dengan Hukum dapat terpenuhi sesuai dengan peraturan yang berlaku.

\section{References}

[1] Inter-Parliamentary Union \& UNICEF, Improving the Protection of Children in Conflict with the Law in South Asia: A r egional parliamentary guide on juvenile justice, UNICEF ROSA, 2006.

[2] Anna Volz, Advocacy Strategies Training Manual: General Comment No.10: Childrenes Rights in Juvenile Justice , Defence for Children International, 2009. 
[3] Barbara Henkes, The Role of Education in Juvenile Justice in Eastern Europe and The Farmer Soviet Union, Constitutional \& Legal Policy Institute, Hungary, 2000.

[4] http://ojs.unud.ac.id/index.php/kerthawicara/article/viewFile/8316/6199 diakses pada, 13 Agustus 2016, 11.05 WIB

[5] http://hariklaten.blogspot.com/2009/12/pendamping-abh.html diakses pada 14 Agustus 2016, 22.00 WIB 